\title{
A daily Low-threshold Integration Center for the Homeless. Model of Social and Healthcare for Excluded Populations
}

G. Herdics (Gyorgy Herdics)1,2, K. Prochazkova (Katerina Prochazkova)1,2, M. Mikloskova (Monika Mikloskova)2, G. Mikolasova (Gertruda Mikolasova)1,2, M. Olah (Michael Olah)1,2, R. Kovac (Robert Kovac) 1,2 5. Tordova (Sandra Tordova)', M. Gliganic (Matej Gliganic)', V. Novak (Vladimir Novak)², C. Matuschek (Carsten Matuschek)2, L. Bucko (LadislavBucko)², M. Karvaj(Marian Karvaj)2,3, J. Benca (Juraj Benca) ${ }^{2}$, M. Jankechova (Monika Jankechova)2,3 M. Mrazova (Mariana Mrazova)2,3, L. Radkova (Libusa Radkova)2,3, P. Tomanek (Pavol Tomanek)2,3, D. Thimm (Dora Thimm)2, A. Ondrejkova (Anna Ondrejkova)², J. Vallova (Jana Vallova)2,3 and S. Kara $\left(\right.$ Sergej Kara) ${ }^{1}$

Original Article

1 Vagus and St. Elizabeth University shelters for homeless, SK

2 St. Elisabeth University PhD and MSc. Program, Bratislava, SK

${ }^{3}$ St. Lesley College, Nove Zamky, SK

\section{E-mail address:}

georgiuspaulus@gmail.com

\section{Reprint address:}

Gyorgy Herdics, Ph.D., MBA

St. Elisabeth University, Bratislava

P. O. Box 58

93005 Gabcikovo, SK

Suource: Clinical Social Work and Health Intervention

Pages: $19-22$
Volume: 8

Issue: 1

Cited references: 13

\section{Reviewers:}

Michael Costello, MA, MBA, J.D.

University of Scranton School of Education, USA

Dr. Andrea Shahum, MD

University of North Carolina at Chapel Hill School of Medicine, USA

\section{Key words:}

Homeless, Vulnerable populations, Social exclusion, Infectious diseases.

\section{Publisher:}

International Society of Applied Preventive Medicine i-gap 
CSWHI 2017; 8(1): 19 - 22; DOI 10.22359/cswhi_8_1_04 @ 2017 Clinical Social Work and Health Intervention

\section{Abstract:}

Vulnerable populations, such as homeless people often have limited access to healthcare and use emergency departments of hospitals for the majority of their medical problems. This leads to increased costs for hospitals and longer waiting times for acute cases. Low-threshold centers for the homeless are good examples of how to integrate this population, at least partially, into society. Having the possibility of complex medical care in these facilities is a good model of care. Most of the patients have various infectious diseases including seasonal flu and SSTI; various wounds and injuries. Psychological disorders and alcoholism are another serious issue which needs addressing. Besides, this kind of approach can attract more clients, even those who are not in need for shelter.

\section{Conflict of interest:}

The authors whose names are listed in the title of the article certify that they have NO affiliations with or involvement in any organization or entity with any financial interest (such as honoraria; educational grants; participation in speakers' bureaus; membership, employment, consultancies, or other equity interest), or non-financial interest (such as personal or professional relationships, affiliations, knowledge or beliefs) in the subject matter or materials discussed in this manuscript.

\section{Introduction}

The number of homeless population in EU is increasing. The homeless population is in substantial risk of medical, psychiatric, and social problems including tuberculosis, HIV infection, hepatitis, alcoholism and substance abuse, skin and foot disease, schizophrenia and related psychoses, malnutrition, and trauma. The homeless are also less likely to be integrated into the primary care system and routinely utilize emergency departments for a majority of their healthcare needs. This is associated with significant healthcare costs which could be prevented by using primary care centers for the homeless which are usually run by NGO's. Furthermore, neither the exact number of such people nor the spectrum of diseases in this population in post-communists countries has not been properly identified. In the capitol Bratislava and in the second largest city Kosice, the same estimated number of homeless is around 3,000 people. The aim of this paper was to describe the commonest infectious diseases present in a low-threshold center for the homeless and to and to evaluate the contribution of a doctor in such a project.

\section{Patients and Methods}

This study was conducted between 20122017 in Bratislava where this center serves for about 3-4,000 homeless population. The shelter is integrating outdoor homeless clients from the capitol and surrounding cities and cooperates with street workers who are actively seeking clients. Treatment also is provided right on the street for clients who don't want or are not able to come to center. 
Since 2014, there is a doctor available in center once a week for more difficult cases with possibility of referring patients for further treatment to a Specialist in hospital. In total, 1,349 patients were treated, some of them more than once, and more than 2,300 diagnoses have been made. There were approximately 30 patients per doctor per day.

\section{Results and Discussion}

The most frequent health problems varied according to the season; in winter, most common were various injuries, ulcers, infected wounds, abscesses and frostbites. On the other side, in summer, different types of skin infections, such as impetigo, rose, microbial eczema, fungal infections and abscesses were most common.

\section{Table 1 Percentage of infectious diseases} according to the season:

Autumn - Winter

- Bronchitis acute $20 \%$

- Leg ulcer $19 \%$

- Injuries, infected wounds $15 \%$

- Tonsillitis $12 \%$

- Infected eczema $10 \%$

- Chronic complications of alcohol dependence $7 \%$

- Scabies, lice 5\%

Spring - Summer

- Impetigo $21 \%$

- Asthma bronchial $17 \%$

- Atopic dermatitis $11 \%$

- Injuries, infected wounds $10 \%$

- Lice, scabies 9\%

- Acute conjunctivitis 7\%

- Psychiatric disorders, depression 5\%

The other significant group of diseases were psychological, mainly depressions, suicidal behavior, alcoholism and alcoholism related conditions, such as epilepsy. Infectious diseases also had a seasonal character; influenza, tonsillitis, bronchitis, sinusitis and pneumonia were most common, typically arising in November and lasting up to March.

\section{Conclusion}

The homeless population remains excluded from society. Healthcare is often unaffordable due to debts to health insurance companies and patients are non-compliant. Low-threshold centers with availability of a doctor seem to be a good model to ensure healthcare for the homeless population. However, this option is still not widely used nor supported. We recommend this model for every institution working with homeless population. Psychiatrist and Psychotherapist would be an important benefit for this community as well. Wider cooperation with Specialists is also recommended.

\section{References}

1. SABO A, MULI MUTUKU J, LISKOVA A, KISAC P, JURIS P, KALAVSKY E, MIKOLASOVA G, MATEICKA F (2013) Viral infections Tropical infectious diseases emerging in the tropics and Social work in marginalized population.

2. CONNOLY MA, LEZCANO G, SHAHUM AG, CAUDA R, KRCMERY VC - Nairobi: AMREF Publ. House, Nairobi,. - ISBN 9789966-21-208-3. - (2013) s. 59-94.

3. MOJTOVA M., SEDLAROVA K., SRANK M. (2013). Clinical social worker. Nitra: Univerzita Konštantína Filozofa v Nitre, 2013, 263 p. ISBN 978-80-558-0269-5.

4. KALAVSKA A, ROZINOVA L, DOBRODENKOVA S, MIKOLASOVA P, TOMOVA S, KRCMERY V, MIKOLASOVA G, ALUMBASI TL (2015) Imported tropical diseases in international travelers, migrants and homeless travelers between 2000-2012; overview of 179 cases in a single Travel Clinic. Clinical Social Work/Peter G. Fedor-Freybergh, Michal Olah. - Vienna: I-GAP, Vienna, - ISSN 2222-386X. - Vol. 5, No. 2 (2015) s. 9-16. 
5. BARTOSOVIC I (2016) Health shelters of elderly and homeless, Bratislava, Med Jan. 98334

6. GALLAGHER TC, ANDERSON RM, KOEGEL P (1997) Determinants of regular sources of care among homeless adults in Los Angeles. Med Care; 35:814-30

7. MIKLOSKOVA, M. (2016). Meeting the family circle - Family Group Conferences. The company Smile as a gift Bratislava, 2016. 103 p. ISBN 978-80-970879-7-5

8. PADGETT DK, STRUENING EL, ANDREWS H (1995) Predictors of emergency use by homeless adults in New York City: the influence of predisposing, enabling, and need factors. Soc Sci Med.;41:547-56.

9. ARCH S, LEAKE B, KNOWLES L, GELBERG L (1998) Tuberculosis in homeless patients: potential for case finding in public emergency departments. Ann Emerg Med.; 32:144-7.

10. SALIT SA, KUHN EM, HARTZ AJ (1998) Hospitalization costs associated with homelessness in New York City. New England J Med.; 338:1734-40.

11. OLAH M, MRAZKOVA I, KOVACS K, ONDRUSOVA Z, BOZIK J, KOLLAROVA A, HUNYADIOVA S, VALLOVA J. (2011) Legal adaptation of Socio-Legal Protection of Children and Social Guardianship in Slovak Republic. In: Clinical Social Work 3/2011. Vienna: International Schientific Group of Applied Preventive Medicine, 2011. - 182 s. - ISSN 2076-9741.

12. FAZEL S, GEDDES JR, KUSHEL M (2014). The health of homeless people in high-income countries: descriptive epidemiology, health consequences, and clinical and policy recommendations. The Lancet, 384(9953), 1529-1540. doi:10.1016/s01406736(14)61132-6

13. DUDOVA Z, TRILISINSKAYA1 Y, JACKULIAKOVA T, JANKECHOVA M, SASVARY F, MATEL A, HAJJ ALI IA (2016). Six month follow up in communicable versus non-communicable diseases in an Iraqi refugee camp. Clinical Social Work and Health Intervention, 7(3), 38-41. doi:10.22359/cswhi_7_3_10

14. ARNAUD A, CHOSIDOW O, DÉTREZ M, BITAR D, HUBER F, FOULET F, VANDENTORREN S (2015) Prevalences of scabies and pediculosis corporis among homeless people in the Paris region: results from two randomized cross-sectional surveys (HYTPEAC study) British Journal of Dermatology, 174(1), 104-112. doi:10.1111/ bjd. 14226 